\title{
COMMON FORMS OF GERRYMANDERING IN THE UNITED STATES
}

\author{
Alex Keena* \\ Virginia Commonwealth University
}

Michael Latner**

The Union of Concerned Scientists and Cal Poly, San Luis Obispo

\author{
Anthony J. McGann*** \\ University of Strathclyde, Glasgow
}

\author{
Charles Anthony Smith**** \\ University of California, Irvine
}

\begin{abstract}
Gerrymandering is a form of voting manipulation whereby electoral district boundaries are drawn to produce a partisan or political bias in elections. In this paper, we study partisan gerrymandering in the United States to understand its undemocratic outcomes and how the design of election institutions can promote or prevent gerrymandering. We begin with a survey of the history of gerrymandering, with a particular focus on partisan gerrymandering. We then consider the normative standards of fairness in democracy that partisan gerrymandering may violate. Next, we present a typology of partisan gerrymandering based upon the district maps drawn in California, Pennsylvania, Massachusetts, and New Jersey for the 2012 elections. Using the partisan symmetry method, we estimate the seats/votes curves of the congressional maps used in 38 states during the 2012 elections. We find that partisan gerrymanders occur almost exclusively when politicians are given control over redistricting. This analysis implies that a political

* Alex Keena, Virginia Commonwealth University, 907 Floyd Ave, Richmond, VA 23284, USA, keenaja@vcu.edu

** Michael Latner, The Union of Concerned Scientists and Cal Poly, San Luis Obispo CA 93407, USA, mlatner@calpoly.edu

*** Anthony J. McGann, University of Strathclyde, 16 Richmond St, Glasgow G1 1XQ, Great Britain, anthony. mcgann@strath.ac.uk

**** Charles Anthony Smith, University of California, 3151 Social Science Plaza, Irvine, CA 92697-5100, USA, casmith@uci.edu
\end{abstract}


designer, who wants to minimize gerrymandering, should not put redistricting in the hands of politicians.

Key words: gerrymandering; voting manipulation; U.S. congress; political parties.

\section{NAJCZECSTSZ SPOSOBY MANIPULACJI KSZTAETEM OKRĘGÓW WYBORCZYCH W STANACH ZJEDNOCZONYCH}

Streszczenie: Gerrymandering jest forma manipulacji głosowaniem, w ramach której wyznacza się granice okręgów wyborczych, aby uzyskać pewne polityczne korzyści w wyborach. W tym artykule badamy gerrymandering partyjny $w$ Stanach Zjednoczonych, aby zrozumieć jego niedemokratyczne wyniki i sposób, w jaki projektowanie instytucji wyborczych może promować lub zapobiegać gerrymanderowaniu. Zaczynamy od przegladu historii gerrymanderingu, ze szczególnym naciskiem na gerrymandering partyjny. Dalej rozważamy normatywne standardy bezstronności $w$ demokracji, które taka manipulacja może naruszać. Następnie przedstawiamy typologię manipulacji na podstawie map okręgów w Kalifornii, Pensylwanii, Massachusetts i New Jersey podczas wyborów w 2012 r. Przy użyciu metody symetrii partyjnej szacujemy krzywe mandatów/głosów map kongresowych uzytych w 38 stanach podczas wyborów w 2012 r. Okazuje się, ze manipulacja gerrymanderingiem występuje prawie wytacznie wtedy, gdy politycy maja kontrole nad wyznaczaniem granic okręgów. Nasza analiza sugeruje, ze jeśli przy projektowaniu systemu wyborczego chcemy zminimalizować manipulację kształtem okręgów, decyzje o poprawkach ich przyszłego kształtu nie powinny być oddane $w$ ręce polityków.

Stowa kluczowe: gerrymanderyzm, manipulacja wyborcza, Kongres Stanów Zjednoczonych, partie polityczne.

Gerrymandering is the deliberate manipulation of electoral district boundaries for personal or political gain. In legislative bodies, such as the U.S. Congress, in which elected officials represent distinct geographic constituencies, district lines demarcate the spatial boundaries between constituency populations. The practice of updating and revising district lines-which is referred to as "redistricting" in the United States-can be exploited to achieve political objectives, such as the manipulation of election outcomes.

The U.S. Constitution requires that the House of Representatives is redistricted every 10 years, after the 435 seats in the assembly are reapportioned to states 
based on population, so that the districts in each state have approximately equallysized populations. Historically, each state has been given the latitude to redistrict is own congressional map, and many state legislators have used this authority to draw gerrymanders.

Recently the United States Supreme Court-the court of last resort in the U.S.issued a ruling that effectively legalized the practice of partisan gerrymandering, a type of gerrymandering in which district lines are drawn to give a political party (or parties) an electoral advantage. The ruling made news headlines across the world because it drew attention to the limits of representative democracy in the U.S., where political party leaders who control state legislatures are free to exploit their control over redistricting in order to achieve undemocratic and partisan goals.

What is gerrymandering? What are its common types? What normative standards of democratic "fairness" does gerrymandering violate? We address these questions in this article with the hope that our analysis will contribute to a growing body of scholarship within the Polish perspective on voting institutions and their pathologies (Flis, 2014; Haman, 2003; Kaminski, 1999; Kaminski, 2002; Kaminski, 2015; Lissowski, 2001; Raciborski, 1997).

We begin with a discussion of the common forms of gerrymandering, with a particular focus on partisan gerrymandering. We then discuss the standard of "partisan symmetry", which borrows a concept from the natural sciences, as a useful way of identifying partisan bias in the seat-vote distribution of a district map in a political system with two-parties. Asymmetrical maps are those which award different shares of seats to two parties for the same share of the vote and thus violate the principle of individual political equality (Hout \& McGann, 2009).

We then discuss three common forms of partisan gerrymandering: the Pennsylvania model, the Massachusetts model, and the New Jersey model. The Pennsylvania model has an asymmetrical distribution of seats that advantages one party over another when the statewide, two-party vote is close. It violates the principles of equality and proportionality, but not necessarily responsiveness. The Massachusetts model is symmetrical, but has a "winner-take-all" distribution of seats that is highly sensitive to statewide swings in the two-party vote. It does not violate equality or responsiveness, but does violate proportionality. Lastly, the New Jersey model is symmetrical in its treatment of two parties, but it is unresponsive to changes in the statewide two-party vote. It does not violate equality or proportionality, but it does violate responsiveness.

We close with an assessment of how the design of redistricting institutions can lead to different forms of partisan gerrymandering under a two-party system. In the U.S. Congress, asymmetrical district maps occur almost exclusively when politicians control redistricting. 


\section{WHAT IS GERRYMANDERING?}

"Gerrymandering" is a concept that means many things to many different people. However, in general, the term refers to the deliberate manipulation of legislative district boundaries in order to achieve some political or personal objective that serves the interests of those in power, who have been charged with drawing the lines. Gerrymandering occurs in electoral systems that assign seats in a legislative body to localized constituencies in order to advance the goal of territorial representation. Gerrymandering is a phenomenon that is typically associated with electoral systems party systems that employ single-member districts, such as the United States or United Kingdom, and which have two parties. However, in principle, any electoral system that assigns representation based on the spatial demarcation of constituency boundaries may be vulnerable to at least some forms of gerrymandering.

The term "gerrymandering" borrows its name from an American politician, Elbridge Gerry, who used his power as governor of the state of Massachusetts in 1812 to approve a state senate district plan that served the interests of his political party, the Democratic-Republicans. However, the practice of manipulating the geographic boundaries of electoral districts predates the founding of the United States. Early forms of gerrymandering can be traced to Great Britain as early as the 1700s, when politicians would draw "rotten boroughs" for which a single neighborhood or city block—or even a single estate-would be drawn into one district, represented by a member of Parliament.

\section{Malapportionment gerrymanders}

The practice of drawing "rotten boroughs" was a form of malapportionment, in which districts are manipulated so that legislators represent vastly different constituency population sizes. In this type of gerrymander, in which districts are created with unequally populated districts, the primary "harm" is the dilution of some citizens' votes relative to others, undermining political equality. In the $18^{\text {th }}$ and $19^{\text {th }}$ century United Kingdom, before the passage of the Reform Act of 1832 which outlawed the practice, the malapportionment of rotten boroughs was advanced to serve the interests of wealthy landowners who used their influence over the districting geography to install their personal interests in Parliament, or to elect their friends or business associates.

Malapportionment also occurred in the United States, although for different objectives. For instance, as recently as the 1960s, state governments would allow urban districts to grow at exponentially faster rates than neighboring rural districts 
without redrawing the district lines to achieve population equity. Here, lawmakers were able to "gerrymander" simply by doing nothing. This had the effect of preserving and consolidating the power of rural districts, whose populations were in long-term decline, at the expense of diluting the influence of urban voters. In this regard, sometimes "gerrymandering" can occur without actually touching the maps, as was the case with "rural gerrymandering".

Figure 1a illustrates how malapportionment works as a tactic for diluting the voting power of one party in order to expand the voting power of another. Because districting authorities are able to draw districts with unequally sized populations, it is relatively easy to give a minority party a majority of seats.

Although our discussion of historical (and hypothetical) examples of malapportionment pertain to representative democracies with two-party systems, in principle, it may also be possible to draw malapportionment gerrymanders in PR systems with more than two parties. This occurs, for example, in the Spanish Congress and Norwegian Storting, where election laws require a minimum allotment of seats to rural communities, resulting in a disproportional advantage for parties representing rural constituents.

\section{Racial gerrymandering}

Another form of gerrymandering that was outlawed in the U.S. after the passage of the Voting Rights Act of 1965, is so-called "racial gerrymandering", in which districts are drawn to dilute the power of racial or ethnic minorities, either through "cracking" (in which minority voters are distributed across multiple districts, thus preventing them from electing representatives of their choosing), or "packing" (in which minority voters are drawn into super-majority districts), or through the use of "winner-take-all", multi-member districts that prevent small plurality populations from winning seats. As Figure $1 \mathrm{~b}$ shows, racial gerrymandering is achieved by "cracking" even when redistricting authorities must draw equally sized districts, when the district lines are drawn to prevent a minority group from gaining a majority in any single district.

\section{Partisan gerrymandering}

Today, the most prevalent type of gerrymandering in the U.S. is "partisan gerrymandering", which is sometimes called political gerrymandering. Although malapportionment and racial gerrymandering were outlawed after the 1960s, the widespread practice of partisan gerrymandering is made possible due to advances in technology and information systems, such as the development of geographic 
information software in the 1980s, as well as a legal loophole in the U.S. that prevents citizens from challenging politically-biased district maps in the federal courts. The effect is that the gerrymanderers are permitted to draw district maps that systematically favor one party over the other, as long as they draw districts with approximately equal populations and do not illegally dilute the votes of minority citizens. Figure 1c shows an example of how one party is able to gain an asymmetrical advantage in seat share. Districting authorities are able to comply with population equity and minority districting requirements, while drawing district lines in such a way that a party with only $30 \%$ of the vote is able to win a majority in two out of the four districts.

\section{Incumbent Protection Gerrymanders}

Another common, but conceptually distinct, type of gerrymandering is the "incumbent protection" gerrymander, in which districts are drawn to include "safe" seats for both parties through the "packing" of voters by party into separate districts. As with partisan gerrymandering, incumbent protection schemes serve the interests of the politicians who control redistricting. However, in contrast to partisan gerrymanders, which advance the interests of one party over another, incumbent protection gerrymanders serve the common interests of two parties.

The effects of drawing "safe" districts are such that incumbent legislators are often easily reelected, and elections in general are uncompetitive and do not translate incremental shifts in two-party support by voters into changes in seat share.

As Figure 1d illustrates, incumbent protection gerrymanders are achieved when districts are drawn with comfortable majorities for each party so that the members defending these districts will not face a serious threat to their power. As Figure 1d demonstrates, it is possible to achieve an incumbent protection gerrymander while satisfying population equity and minority representation. 
(a) Malapportionment

\begin{tabular}{|c:ccc|}
\hline 0 & 0 & 0 & 0 \\
0 & 0 & 0 & 0 \\
0 & 0 & 0 & 0 \\
0 & 0 & 0 & 0 \\
\hdashline$x$ & $x$ & 0 & 0 \\
0 & 0 & 0 & 0 \\
$x$ & 0 & 0 & $X$ \\
$x$ & 0 & $x$ & $x$ \\
0 & $x$ & $x$ & 0 \\
$x$ & $x$ & 0 & $X$ \\
\hline
\end{tabular}

(c) Partisan Gerrymandering (b) Racial Gerrymandering

\begin{tabular}{|c:ccc|}
\hline 0 & 0 & 0 & 0 \\
0 & 0 & 0 & 0 \\
0 & 0 & 0 & 0 \\
0 & 0 & 0 & 0 \\
$x$ & $x$ & 0 & 0 \\
0 & 0 & 0 & 0 \\
$x$ & 0 & L & 0 \\
$x$ & 0 & $x$ & $x$ \\
0 & $x$ & $x$ & 0 \\
$x$ & $x$ & 0 & $x$ \\
\hline
\end{tabular}

(d) Incumbent Protection

\begin{tabular}{|c|c|c|c|}
\hline 0 & 0 & 0 & 0 \\
\hline 0 & 0 & 0 & $\mathrm{O}$ \\
\hline 으. & $\underline{O}$ & 0 & 0 \\
\hline 0 & 0 & 0 & 0 \\
\hline$x$ & $x$ & 0 & 0 \\
\hline - $\underline{0}$ & 0 & 0 & 0 \\
\hline$x$ & 0 & 0 & $X$ \\
\hline$x$ & 0 & $x$ & $X$ \\
\hline 0 & $\mathrm{X}$ & $x$ & 0 \\
\hline$x$ & $x$ & 0 & $X$ \\
\hline
\end{tabular}

\section{Figure 1. Common types of gerrymandering and how they work}

Imagine a "state" that is awarded four seats in the national assembly, with an even spatial distribution of voters, with 40 voters that align with two parties, represented by $\mathrm{o}$ ( 28 voters) and $\mathrm{x}$ (12 voters), and belong to two different race groups, represented by lowercase letters (30 voters) and uppercase letters (10 voters). In the "malapportionment" model, districting authorities are not required to maintain population equity. Therefore, they are free to dilute the vote of the majority party in order to give the minority party three out of four seats. In the "racial gerrymandering" model, districting authorities are required to draw districts with equal population, but they can do so in a way that dilutes the votes of the minority race group, such that while different parties win seats, they all go to the majority (lowercase) race group in all four districts. In the "partisan gerrymandering" model, districting authorities must district with equal population and they must draw a majority uppercase district, but the minority party is still able to win two of the four seats. In the "incumbent protection" model, voters are "packed" into districts by party so that incumbents from both parties win their districts with large majorities. 


\section{GERRYMANDERING AND VIOLATIONS OF DEMOCRATIC NORMS}

The concept of partisan gerrymandering is inherently difficult to formalize. The lack of a clear legal standard for identifying unlawful partisan gerrymanders was among the reasons cited by the U.S. Supreme Court when it decided that the U.S. federal judiciary was not capable of providing a legal remedy for the problem of partisan gerrymandering (Rucho v. Common Cause, 2019). However, the social sciences offer an intuitive and relatively simple approach for identifying partisan gerrymanders and for quantifying their democratic "harms".

In this section, we discuss normative standards of democratic fairness that common forms of partisan gerrymandering often violate. Although, in principle, the practice of gerrymandering may serve to undermine many distinct democratic norms, for the sake of simplicity we focus on three normative standards of democratic fairness that common types of partisan gerrymanders violate: (1) political equality; (2) responsiveness; and (3) proportionality. We then present empirical standards in the social sciences for identifying violations of these fairness criteria.

\section{Political equality and partisan symmetry}

The norm of political equality is based upon the intuition that a "fair" democracy is one that imposes the same set of rules on everyone, and that weighs all citizens' votes equally in the determination of social choices. Violations of political equality occur when a district map produces counter-majoritarian outcomes, for example, by awarding a majority of seats to a party with a minority of votes (Hout \& McGann, 2009; McGann et al, 2015; McGann et al, 2016). However, for violations of political equality to occur does not necessarily require that unequal outcomes are realized. For example, suppose there is a football match between two teams and the rules state that one team is to defend a regulation-sized goal while the other team gets to defend a smaller goal. Such an arrangement is normatively unfair, because one team confronts a different set of standards than the other. These rules violate the standard of equality, because they impose different rules on each team. However, suppose that, over the course of the match, the team defending the larger goal was never able to attempt a shot on the other team's (smaller) goal. Here, we would still say that the standard of equality was violated, even if the consequences of an unfair set of rules did not affect the outcome of this particular match. Accordingly, violations of equality do not necessarily require that unfair outcomes are realized.

The concept of "partisan symmetry" is a useful way of identifying violations of equality in district maps-even if unequal outcomes are theoretical and never 
actually occur in reality_and has the advantage of measuring the degree to which two parties are treated equally over a wide range of vote totals. Partisan symmetry has been used by scholars as a standard for identifying and comparing partisan gerrymanders for several decades (Gelman \& King, 1990, 1994a, 1994b; Grofman \& King, 2007; Tufte, 1973).

The concept of "symmetry" is borrowed from the natural sciences. The basic intuition is that fairness in districting occurs when parties are treated similarly under similar circumstances - that is, when the two parties are awarded a similar share of the seats when they achieve a similar share of the votes. For example, suppose that Party A gets $60 \%$ of the seats by winning $55 \%$ of the vote. Under a symmetrical district map, Party B would also get $60 \%$ of the seats if it wins $55 \%$ of the vote. Note that the standard of symmetry does not require proportionality, but only that the disproportionality be the same for both parties. It is fine by this standard to give all the seats to Party A if it gets $60 \%$ of the vote, provided that Party B would also get all the seats if it were to win $60 \%$ of the vote.

Accordingly, the symmetry of a district map can be used to identify violations of political equality. A symmetrical map treats both parties similarly under similar circumstances, and therefore always awards the most seats to the party with the most votes. However, an asymmetrical map that is biased to give a seat-share advantage to one party over another, under some range of the statewide two-party vote, violates the equal treatment of voters' preferences. Indeed, for political equality to occur, an electoral system must necessarily award a majority of seats to a party that wins a majority of votes, assuming weak monotonicity (for a formal explanation, see Hout \& McGann, 2009). Therefore, violations in the symmetrical distribution of seats for votes signal that a district map is normatively unfair because it imposes different sets of standards on each party.

\section{Responsiveness}

"Responsiveness" is the notion that electoral outcomes are determined by the preferences of voters-in other words, that changes in voters' preferences should lead to corresponding changes in seat allocation. Violations of responsiveness occur when a district map leads to seat share outcomes that do not change when voters' two-party preferences change. Such maps are "unfair" because they subvert the will of voters in their determination of outcomes. Accordingly, "fair" district maps are those that are sensitive (in terms of their two-party seat allocation) to changes in twoparty vote support. 
Partisan symmetry also offers an empirical approach for identifying violations of responsiveness in a district map. The responsiveness of district map is indicated by slope of the seat/vote curve of a district plan that determines how vote support is allocated into seat share. A district map is highly responsive when the slope of the seats/votes curve is very high, which means that it awards a surplus of seats for incremental shifts in the vote. Conversely, a district map is unresponsive when the slope of the seats/votes curve is flat, which means that large increases in vote share do not yield corresponding changes in seat share.

\section{Proportionality}

"Proportionality" is the idea that the number seats awarded to a party is proportionately linked to the number of votes it has won. Non-proportional outcomes are normatively "unfair" when they ignore minority preferences, or when they deny a majority party a majority of the vote.

In the strictest sense, perfect proportionality requires that a party with $n \%$ of the vote share will win $n \%$ of the seat share in a legislature. However, in practice, very few democracies achieve perfect proportionality. Many PR systems allocate some bonus of seats to the plurality winner, and in first-past-the-post electoral systems it is generally expected that the most favored choice will receive a surplus of seats (McGann, 2006; Taagapera \& Shugart, 1989). However, in the U.S., there is a normative expectation that an electoral system should award some seats to sizable minority parties, and that it is unfair to when one party is systematically denied representation, or when a party with a majority of the vote share does not win a majority of the seat share. Thus, in practice, we adopt a very loose standard of proportionality when assessing partisan gerrymanders.

As we note above, achieving symmetry does not necessarily imply proportionality in terms of seat-vote allocation (although perfect proportionality implies symmetry). However, partisan symmetry offers insight into the proportionality of a district map, under a range of hypothetical vote outcomes. District plans that violate the concept of proportionality deviate substantially from a seat-vote curve with a slope of 1 , where the seat share (y) is approximately equal to the vote share (x). And it is often the case that highly asymmetrical maps that violate the norm of political equality also violate proportionality. 


\section{ESTIMATING PARTISAN SYMMETRY IN DISTRICT PLANS}

In the previous section, we asserted that the partisan symmetry standard can provide a useful way of evaluating the performance of a district plan in order to identify violations of democratic norms. We estimate the symmetry of a district plan by producing a seat/vote curve that reveals how a plan translates votes into seats under a range of possible electoral conditions. This gives us insight into the extent to which a plan violates normative standards of democratic fairness, and it allows us to classify the most common forms of partisan gerrymandering.

In this section, we discuss how to "measure" the partisan symmetry of a district plan in order to estimate partisan bias. We implement the symmetry measure in the following way. We follow the approach of Gelman and King (1994). However, we do not use the JudgeIt software later developed by those authors, but rather do the estimation ourselves using $\mathrm{R}$ software, using the process that is outlined by McGann et al. (2016).

To summarize, we generate a seats/votes function for each state - that is, how many seats a party would get if it won a certain percentage of the vote in their state. We can calculate this from the actual election results in each district using the assumption that the swing in support between the parties is approximately evenly spread across the districts. ${ }^{1}$ For example, if one party's support increases by $1 \%$ statewide, then this party's support will increase in every district by $1 \%$ (the technical name for this assumption is "uniform partisan swing"). Of course, we realize that in reality there are many local and idiosyncratic factors at work in addition to changes in the aggregate level of party support. For this reason, we run a thousand simulations where the party's support in each individual district is changed by a random amount. (Empirical evidence suggests that these local effects are large, averaging five percentage points.)

From these seats/votes functions we are able to calculate symmetry and responsiveness scores for each state. Symmetry scores measure the degree to which the Democrats and Republicans receive the same number of seats in their U.S. House of Representatives delegation for the same seat share - a score of 0 indicates symmetry, while $100 \%$ means the Democrats get all the seats if their vote share is between $45 \%$ and $55 \%$ and $-100 \%$ means that the Republicans get all the seats under the same conditions. The measure of symmetry at a certain level of vote is defined as the difference between the seat share Party A gets for that level of vote (say 55\%) and the seats share Party B would get if it were to win that level (again 55\% in our

1 We used the two-party vote share in each district. In districts where both parties did not run, we used the Presidential vote apportioned over the Congressional district as an instrument to estimate the relative support of the two parties. 
example) of the vote. To calculate a symmetry score for each map, we follow Gelman and King (1994b) and calculate the average of this symmetry measure at all levels of vote between $45 \%$ and $55 \%$. Responsiveness scores represent the average slope of the seat/vote curve between $45-55 \%$ of the statewide two-party vote.

\section{COMMON FORMS OF PARTISAN GERRYMANDERING}

Through the method described above, we are able to draw comparisons between the congressional district maps that each state enacted after the most recent redistricting cycle, which occurred in 2011. In this section, we highlight common forms of partisan gerrymanders by comparing actual redistricting maps adopted by U.S. states. The seats/votes curves that we have generated for each state illustrate distinct forms of gerrymandering, and how they violate different normative standards of fairness in democracy.

First, as a reference, we illustrate a "fair" map that was passed in California, which adheres to all three of the normative fairness criteria we have discussed. Figure 2 shows that seats-votes curve in California's congressional map, based upon the results of the 2012 elections.

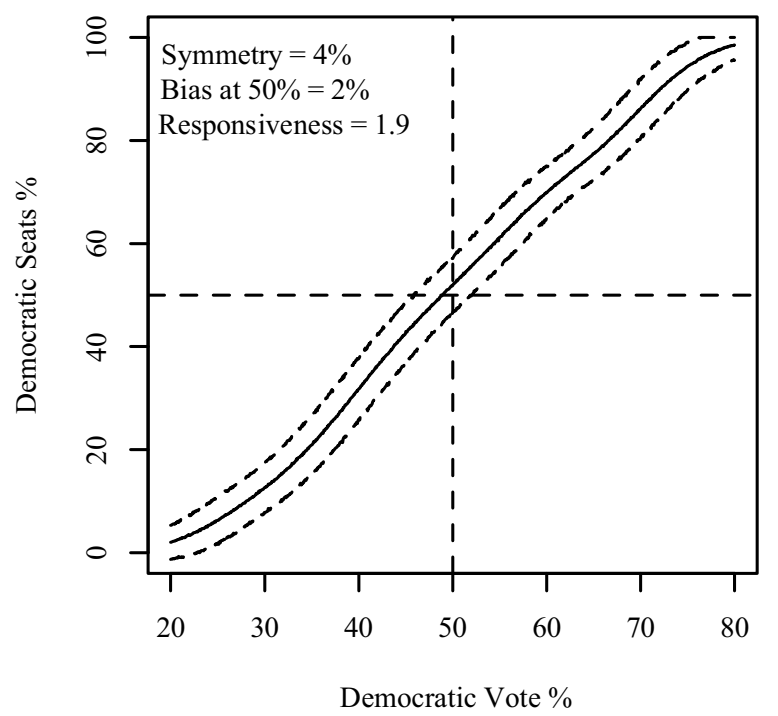

Figure 2. Seats/votes function for California in 2012, based on data published by McGann et al, 2016 (dotted line +/- 2 standard deviations) 
As is evident, the map is effectively symmetrical in terms of its treatment of the two parties. The seat-votes curve is close to a straight line, which means that the map treats both parties equally under a wide range of possible vote share outcomes. Because the map is symmetrical in its treatment of the two parties also means that it does not violate the normative standard of political equality. When the Democratic Party receives 50\% of the statewide vote, the Democrats are awarded approximately $50 \%$ of the seats, statewide. Thus, when a majority of voters support one party over another (say the Democrats), then the Democratic Party ends up winning a majority of seats.

The map is also responsive insofar as it is sensitive to swifts in the will of voters. The slope of the seats-votes curves is approximately 1.9 , which means that a one percent increase in support for one party translates to a nearly two percent increase in that party's seat share. Thus, the map is sensitive to changes in voters' preferences.

Lastly, the map is effectively, although not perfectly, proportional. Although pure proportionality requires a seats-votes slope of one, the California map is relatively close to this value. The map is effectively proportional when the two-party vote is close, and it performs particularly well along this criterion compared to other firstpast-the-post systems. Indeed, in almost all hypothetical vote outcomes, a minority party can expect to receive some share of seats.

In sum, the California Map is "fair" in that it achieves the normative, democratic standards of political equality, responsiveness and proportionality. The parties are treated equally under equal circumstances, and the map is sensitive to shifts in vote support without deviating from proportionality. Accordingly, the California model provides a nice baseline with which to compare other maps that violate normative standards of fairness.

\section{The Pennsylvania model}

In contrast to California, which produced a map that was symmetrical, unbiased, and responsive, Pennsylvania produced a congressional district map that is biased to favor the Republican Party. Although the state tends to be competitive - both Democratic and Republican candidates won statewide elections for governor and lieutenant governor in the decade before redistricting - the map awards a disproportionate share of seats to Republicans when the statewide two-party vote is close. Indeed, in the 2012 congressional elections, the Democratic candidates managed to win a majority of the two-party vote statewide; however, of the 18 seats contested, Democrats only won 6 ! 
The biases of the Pennsylvania map are illustrated in Figure 3. What is striking is the degree to which the seats/votes curve deviates from symmetry, compared to the California map. Thus, the map very clearly violates the norm of political equality: it is unfair insofar as the Republicans almost always do better than Democrats for a given share of the vote. This has the effect of discounting the preferences of voters who choose Democratic candidates.

Notwithstanding, the map does not necessarily violate the standard of responsiveness. Although the map is less responsive when the Democratic vote share is small and more responsive when the Democratic vote share is high, on average, it does appear to be sensitive to changes in two-party preferences of voters. It is moderately responsive between $45 \%$ and $55 \%$ of the vote - its score is 1.4.

However, the map does appear to violate even "loose" standards of proportionality. This is particularly so when the two-party vote is close. Note that when the vote share is around $50 \%$, the seat share is highly disproportional in its favoring of Republican candidates. At $50 \%$ of the vote, the Democrats expect to win about $30 \%$ of the seats, while the Republicans can expect to win about $70 \%$ of the seats.

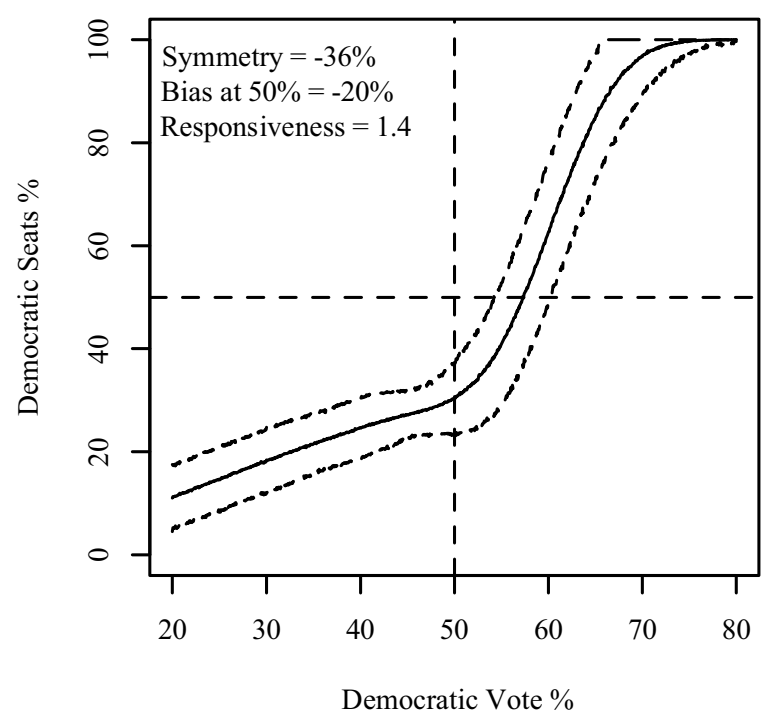

Figure 3. Seats/vote function for Pennsylvania, based on data published by McGann et al, 2016 (dotted line +/- 2 standard deviations) 
In sum, the Pennsylvania Model is one of the most common forms of partisan gerrymandering. The effect of this map is that it gives one party an asymmetrical advantage by diluting the votes of the other party, in a state that is typically competitive. Here, districting authorities were able to achieve Republican bias by "packing" Democratic support around Philadelphia and Pittsburgh into a five heavilyDemocratic districts. The symmetry score is about $36 \%$ in favor of the Republicans, which means that Republican candidates can expect to win about $36 \%$ more seats than Democrats on average for a given share of the two-party vote.

\section{The Massachusetts model}

Another form of partisan gerrymandering is embodied by the map passed in Massachusetts. This plan is an unbiased, "winner-take-all" plan. It is approximately unbiased, as can be seen from the symmetry of the graph, which is shown on Figure 4.

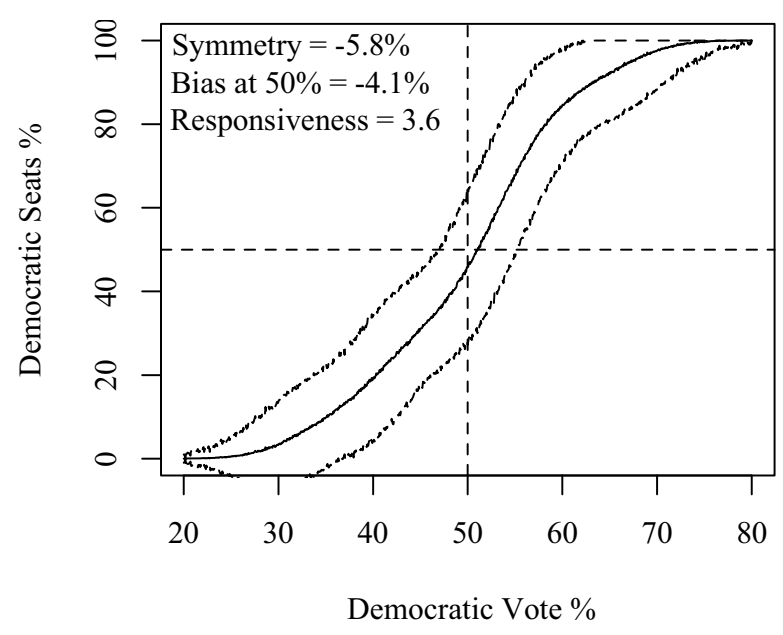

Figure 4. Seats/votes function Massachusetts 2012, based on data published by McGann et al, 2016 (dotted line +/- 2 standard deviations)

As is evident, the map is effectively symmetrical. Although the seats-votes curve isn't a straight line, as we saw with California, the map treats both parties equally under equal circumstances. In this regard, it is unbiased. (There is actually a small bias towards the Republicans, but this is not statistically significant.) When the Democrats get a certain share of the vote-for example, $60 \%$ - they receive $80 \%$ of the seats. The same applies to Republicans: when they get $60 \%$ of the vote, they also get about $80 \%$. Likewise, whereas the Democrats take all of the seats for about $75 \%$ 
vote, the Republicans would also take all of the seats if they were to achieve $75 \%$ of the statewide vote. Moreover, the seats-votes curve passes through the 50\%-50\% point, which means that it necessarily awards a majority of seats to the party with the majority of votes. Thus, the plan does not violate the standard of political equality. Citizens are treated equally insofar as their party gains a majority of seats when it receives a majority of the statewide vote.

The Massachusetts model is also highly responsive between $40 \%$ and $60 \%$ of the vote. Although the slope of the seats-votes curve varies, the average slope when the statewide vote is close is about 3.6. This means that the map is highly sensitive to small shifts in two-party vote. When one party receives an increase in vote share of one percent, they are rewarded with $3.6 \%$ more in seat share.

However, the Massachusetts Model does appear to violate proportionality, even by the loosest of standards. Although the plan is approximately proportional when the two-party vote is close, incremental shifts in voter support correspond with exponential increases in seat awards. The map effectively serves as a symmetrical "winner-take-all" plan. When one party dominates statewide (which has historically been the case with the Democrats in Massachusetts), that party is able to win all ten of Massachusetts seats. However, the plan is not biased. If the Republicans were to win $65-70 \%$ of the vote in Massachusetts, they would also win all ten seats.

This plan is politically appealing in a state where one party is dominant and a second party wins only about a third of the statewide vote in an average election. Under these conditions, the minority party is effectively prevented from winning any seats, and the majority party's dominance is maximized.

Thus, one might argue that the Massachusetts plan is "fair" in some ways and "unfair" in other ways. In normative discussions, some might argue that the plan is not a partisan gerrymander, insofar as it treats the two parties symmetrically. However, others might contest that the plan is a partisan gerrymander because it is designed to exclude minority party voters from the state's congressional delegation.

\section{The New Jersey model}

Another form of gerrymander used in the U.S., which is less common, is exemplified by the congressional plan enacted by New Jersey in 2011, which is illustrated on Figure 5. The New Jersey model plan effectively serves as an "incumbent protection" plan. The plan is symmetrical - its symmetry score is about -6 , although this is well 
within the statistical margin of error. In this regard, it treats both parties equally under a range of vote possibilities, and accordingly does not violate the norm of political equality.

However, the plan is non-responsive, particularly between $45-55 \%$ of the vote. This has the effect of insulating both parties from changes in two party vote support when the vote is close. Such a plan is appealing in states like New Jersey, where two-parties must work together in order to draw a district map. The effect is collusion by the political parties against the voters. The non-responsiveness of the map during normal electoral conditions means that neither party's incumbents lose elections and can be assured victory. In this way, the map is normatively "unfair", because the outcomes are determined irrespective of the preferences of voters, and elections are effectively symbolic.

The plan also deviates from proportionality in some circumstances. When the two-party vote is close, both parties can expect a roughly equal share of seats. This was precisely the case for the congressional elections in 2012 and 2014 - both the Republicans and Democrats each took home six seats, despite the fact that, in both elections, the Democrats won a sizable majority of the statewide two-party vote. However, the plan does not punish a smaller party by denying them seats-indeed, under nearly all electoral outcomes, both parties end up winning some seats.

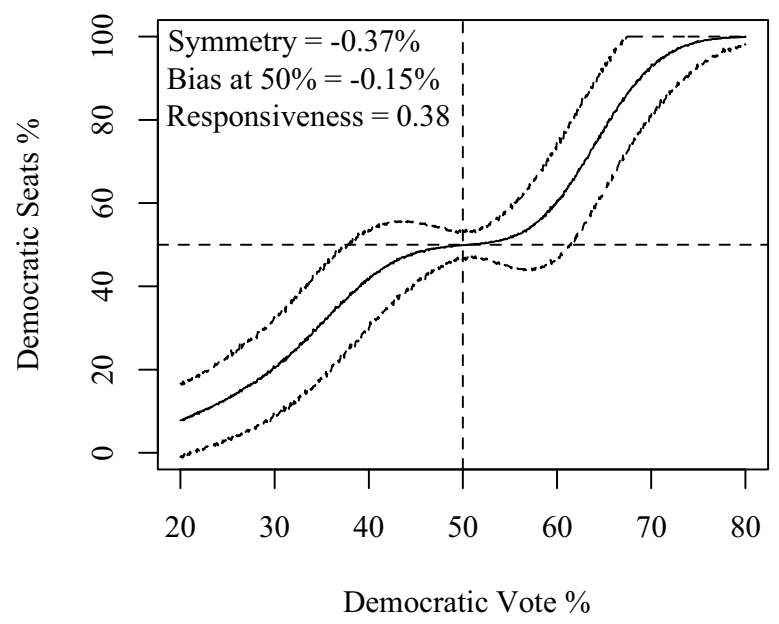

Figure 5. Seats/votes function New Jersey 2012, based on data published by McGann et al, 2016 (dotted line +/- 2 standard deviations) 


\section{GERRYMANDERING AND POLITICAL REDISTRICTING}

In the previous section, we presented examples of common partisan gerrymanders in the United States. In this section, we consider how "political redistricting" leads these forms of gerrymandering. Political redistricting occurs when state laws delegate redistricting authority to a political body, such as a state legislature. While most states have adopted political redistricting, some states delegated control of redistricting to a non-political body, such as an independent redistricting commission or court.

As a simple way to assess the links between political redistricting and partisan gerrymandering, we used the symmetry score estimates of the congressional maps used in 2012 elections, for each of the 38 states that have more than two seats in the House of Representatives, based upon the findings of McGann et al (2016). We then applied the gerrymandering typology we presented above in order to classify each map. By comparing these data, we are able to see the types of maps produced by political and non-political redistricting bodies.

As Table 1 demonstrates, partisan gerrymandering occurs almost exclusively in states with political redistricting, while "fair" maps almost always occur in states where a non-political or non-elected body has control over redistricting. For example, we observe several classic partisan gerrymanders of the "Pennsylvania Model" variety, in which the maps are biased to have an asymmetrical distribution of seats to favor one party over another. Of the 19 maps that fell into this form of gerrymandering, 18 of these were drawn by political redistricting bodies, which tended to be state legislatures controlled by one party. The one exception was the map in Texas, which was drawn by a court.

Although the Massachusetts and New Jersey gerrymanders are less common, in every example, the maps were drawn by political bodies. In Massachusetts, Nebraska, Oklahoma, Oregon and Utah, the maps were drawn by the state legislatures. In New Jersey, the maps were drawn by politicians working in a redistricting commission that requires a "balanced" composition of both parties. Thus, it is not surprising that the result of this process was a map that favored incumbent politicians from both parties.

Among the "fair" maps, the effects of non-political districting are apparent. In most examples of unbiased maps that met all three normative standards of fairness, nearly all were drawn by courts or independent commissions that bar politicians from participating. The three exceptions - Arkansas, Illinois, and West Virginia occurred in states where Democratic politicians control the process. 
Table 1

Redistricting control and partisan gerrymandering

\begin{tabular}{|c|c|c|}
\hline & $\begin{array}{c}\text { Congressional maps drawn } \\
\text { by political bodies }\end{array}$ & $\begin{array}{l}\text { Congressional maps drawn } \\
\text { by non-political bodies }\end{array}$ \\
\hline $\begin{array}{l}\text { The California model } \\
\text { - Unbiased, responsive, and proportional }\end{array}$ & Arkansas, Illinois, West Virginia & $\begin{array}{c}\text { Arizona, California, Colorado, } \\
\text { Connecticut, lowa, Kansas, } \\
\text { Minnesota, Nevada, New } \\
\text { Mexico, New York, Washington }\end{array}$ \\
\hline $\begin{array}{l}\text { The Pennsylvania model } \\
\text { - Partisan gerrymander } \\
\text { - high bias, moderate responsiveness, } \\
\text { violates proportionality and political } \\
\text { equality }\end{array}$ & $\begin{array}{l}\text { Alabama, Florida, Georgia, Indiana, } \\
\text { Kentucky, Louisiana, Maryland, } \\
\text { Michigan, Mississippi, Missouri, North } \\
\text { Carolina, Ohio, Pennsylvania, South } \\
\text { Carolina, Tennessee, Virginia, Wisconsin }\end{array}$ & Texas \\
\hline $\begin{array}{l}\text { The Massachusetts model } \\
\text { - "winner-take-all" plan } \\
\text { - low bias, high responsiveness, } \\
\text { but violates proportionality }\end{array}$ & $\begin{array}{c}\text { Massachusetts, Nebraska, Oklahoma, } \\
\text { Oregon, Utah }\end{array}$ & \\
\hline $\begin{array}{l}\text { The New Jersey model } \\
\text { - "incumbent protection" plan } \\
\text { - low bias, proportional, but violates } \\
\text { responsiveness }\end{array}$ & New Jersey & \\
\hline
\end{tabular}

\section{Conclusion}

In this article, we have explored the concept of partisan gerrymandering, one of the most common forms of electoral manipulation in the United States. Through empirical analyses of congressional maps used in several states, we have shown that there are many different forms of partisan gerrymandering and each have distinct effects on democratic norms. Some gerrymanders, such as the Pennsylvania model, are designed to give one party an asymmetrical advantage in elections, and thus violate the norms of political equality and proportionality. Others, such as the Massachusetts and New Jersey examples, do not violate equality, but are harmful in other ways, for example, by violating proportionality or responsiveness norms.

Accordingly, the prevalence of gerrymandering can serve to undermine democratic norms. However, as we saw in the previous section, gerrymandering is not a "natural" phenomenon. Gerrymandering occurs when politicians are given control over redistricting, and we tend to see unbiased non-gerrymandered maps when independent actors are given control. For governments hoping to reform their redistricting processes to prevent partisan gerrymandering, this analysis suggests that non-political districting is one potentially fruitful approach.

The conceptual framework we use to identify partisan gerrymandering and its normative "harms" are applicable to multi-party systems (King, 1990; Magar et al, 2017), and as components of a unified theory of representational bias, should 
contribute to the design of fair electoral systems and the preservation of voting rights (Grofman et al, 1997).

Gerrymandering presents a substantial threat to representative democracy and should be kept in check when possible through non-elected commissions or the judiciary. Any newly emerging or newly consolidating democracy might lose the very democratic responsiveness at the heart of systemic reform if politicians are allowed to choose their voters instead of voters choosing their politicians.

\section{REFERENCES}

Flis, J. (2014). Złudzenia wyboru. Społeczne wyobrazenia i instytucjonalne ramy $w$ wyborach do Sejmu i Senatu. Kraków: Wydawnictwo Uniwersytetu Jagiellońskiego.

Gelman, A., \& King, G. (1990). Estimating the Electoral Consequences of Legislative Redistricting. Journal of the American Statistical Association, 85(410), 274-282.

Gelman, A., \& King, G. (1994a). Enhancing Democracy through Legislative Redistricting. American Political Science Review, 88(3), 541-559.

Gelman, A., \& King, G. (1994b). A Unified Method of Evaluating Electoral Systems and Redistricting Plans. American Journal of Political Science, 38(2), 514-554.

Grofman, B., \& King, G. (2007). The Future of Partisan Symmetry as a Judicial Test for Partisan Gerrymandering after LULAC v. Perry. Election Law Journal, 6(1), 2-35.

Grofman, B., Koetzle, W., \& Brunell, T. (1997). An integrated perspective on the three potential sources of partisan bias: Malapportionment, turnout differences, and the geographic distribution of party vote shares. Electoral Studies, 16(4), 457-470.

Haman, J. (2003). Demokracja, decyzje, wybory. Wydawnictwo Naukowe „Scholar”.

Hout, E., \& McGann, A.J. (2009). Liberal political equality implies proportional representation. Social Choice \& Welfare, 33(4), 617-620.

Kaminski, M.M. (1999). How communism could have been saved: Formal analysis of electoral bargaining in Poland in 1989. Public Choice, 98(1), 83-109.

Kaminski, M.M. (2002). Do parties benefit from electoral manipulation? Electoral laws and heresthetics in Poland, 1989-93. Journal of Theoretical Politics, 14(3), 325-358.

Kaminski, M.M. (2015). Ordynacje większościowe i JOW-y. Kompendium reformatora ordynacji wyborczej. Warszawa: Wydawnictwo Naukowe "Scholar".

King, G. (1990). Electoral Responsiveness and Partisan Bias in Multiparty Democracies. Legislative Studies Quarterly, XV, 159-181.

Lissowski, G. (2001). Elementy teorii wyboru społecznego. Warszawa: Wydawnictwo Naukowe "Scholar".

Magar, E., Trelles, A., Altman, M., \& McDonald, M.P. (2017). Components of partisan bias originating from single-member districts in multi-party systems: An application to Mexico. Political Geography, 57(1), 1-12. 
McGann, A.J. (2006). The Logic of Democracy: Reconciling Equality, Deliberation, and Minority Protection. University of Michigan Press: Ann Arbor, Mi.

McGann, A.J., Smith, C.A., Latner, M., \& Keena, J. A. (2015). A Discernable and Manageable Standard for Partisan Gerrymandering. Election Law Journal, 14(4), 295-311.

McGann, A.J., Smith, C.A., Latner, M., \& Keena, A. (2016). Gerrymandering in America: The House of Representatives, the Supreme Court, and the Future of Popular Sovereignty. Cambridge University Press: New York.

Raciborski, J. (1997). Polskie wybory: zachowania wyborcze społeczeństwa polskiego w latach 19891995. Warszawa: Scholar Books.

Taagepera, R., \& Shugart, M. (1989). Seats and Votes: The Effects and Determinants of Electoral Systems. New Haven: Yale University Press.

Tufte, E. 1973. The Relationship between Seats and Votes in Two-Party Systems. American Political Science Review, 67(2), 540-554. 